\title{
Sources of Speaking EFL Self-Efficacy of Japanese University Students
}

\section{Dawn Kobayashi}

Onomichi City University

\section{Reference Data}

Kobayashi, D. (2021) Sources of speaking EFL self-efficacy of Japanese university students. In P. Clements, R. Derrah, \& P. Ferguson (Eds.), Communities of teachers \& learners. JALT. https://doi. org/10.37546/JALTPCP2020-15

Raising the English-speaking fluency of university graduates is a key concern. The ability to communicate in English serves as a gateway to global education and employment opportunities, at the same time, the English level of Japanese is one of the lowest in Asia. Self-efficacy, which is a person's confidence in their abilities to complete a specific task, may help in understanding why. It is formed through the interpretation of learning experiences and is a predictor of academic success. However, its role in EFL speaking in Japan remains under-researched. Consequently, in this study 15 university students were interviewed about their EFL speaking learning experiences at junior and senior high school in relation to sources of self-efficacy. Findings suggest a tendency for passive speaking mastery experiences, insufficient peer modelling and a strong preference from students for more communicative activities.

大学卒業者の英語力の向上は重要な課題である。英語でのコミュニケーション能力は、グローバルな教育や雇用機会への 入り口となるが、方で日本人の英語レベルはアジアでも最低レベルであるをの理由を理解するには、特定の浬題を成功さ せるための自己効力感 (self-efficacy)が役立つか屯しれない。自己効力感は学習経験の解釈を通して形成され、学業の成功 を予測するものである。か、、日本のEFL スピーキングにおけるその役割については、まだ+分な研究がなされていない。 こで本研究では 15 名の大学生を対象に中学・高校でのEFL スピーキングの学習経験上自己効力感との閉連についてイ

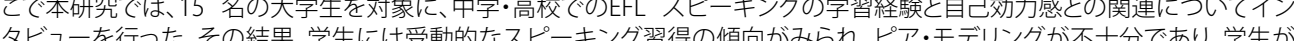
より多くのコミュニケーション活動を好む傾向があることが示唆された。

ultivating the communicative ability of graduates is a significant concern for educationists in Japan because it is an impetus for the internationalisation of higher education institutes and the global expansion of industries (Baker, 2016; Breaden, 2014;
Tsuruta, 2013). Raising the English spoken fluency of graduates has been challenging because Japanese learners of English tend to have weak oral proficiency (Hamada, 2008; Rogers, 2007). Furthermore, the English proficiency level of Japanese people is one of the lowest in Asia with some assessments indicating that the level is decreasing (Education First, 2019).

Japanese students' low proficiency has been attributed to loss of motivation and low willingness to communicate caused by the grammar translation teaching methods used at junior and senior high school (JSHS, hereafter) (Kikuchi, 2009; Munezane, 2015; Murakami et al., 2012; Sakai \& Kikuchi, 2009). These findings suggest that students' experiences at JSHS impact on their current English proficiency and that students do not receive enough speaking practice at school. Therefore, understanding the students' experiences of learning English speaking at JSHS could help researchers identify the causes of students' low proficiency and confidence to speak English. This study investigates students' learning experiences through sources of self-efficacy. In the following sections I outline the background of self-efficacy research in academic contexts and discuss the methodology for the semistructured interviews. Finally, I present the five themes relating to students' sources of self-efficacy experiences and make recommendations for teaching EFL speaking skills.

\section{Self-Efficacy}

Self-efficacy (SE hereafter) is the confidence a person feels in their ability to achieve specific levels of performance (Bandura, 1994) and is a powerful predictor of academic success. Thus, students who have robust sources of self-efficacy experiences develop strong SE which in turn fosters achievement and motivation. Self-efficacy is a core element of Bandura's (2012) influential social cognitive theory which holds that people have the power to influence their actions through the interplay of behavioural, environmental and personal determinants. Although originally formed to alleviate 
the debilitating effects of phobias, research consistently shows that SE levels predict student academic achievement (Zimmerman, 1995), and motivation (Busse \& Walter, 2013; Schunk, 1995). Self-efficacy levels are based on information gathered from four sources: mastery: experiences of success with a task, social modelling: watching similar others complete the task, social persuasion: feedback from significant others about task performance, and physiological states: physical and emotional responses to the task (Bandura, 2012). Self-efficacy in EFL learning has been studied as an aspect of motivation (Dörnyei, 1998; Kormos et al., 2011) with research identifying SE as a powerful indicator of EFL learning success (Burrows, 2016; Templin et al., 2001).

In the Japanese context, EFL SE has been explored in relation to reading and listening skills (Burrows, 2016; Todaka, 2017). Studies that have addressed the speaking confidence of Japanese learners have approached the problem from perspectives such as self-perceived communicative competence (Lockley, 2013), language learning beliefs (Toyama, 2015), or foreign language anxiety (Matsuda \& Gobel, 2004). Research into sources of SE has connected the sources to other educational factors such as achievement, motivation and self-regulated learning (Mills et al., 2007) and concluded that mastery is the most powerful source of SE beliefs (Usher \& Pajares, 2008). However, Oettingen (1995), has argued that this is a Western-centric view and that in collectivist societies, such as Japan, social persuasion is likely to be the most potent source of SE.

The majority of studies have explored the sources of SE for mathematics (Lent et al., 1991; Usher \& Pajares, 2009) and student teachers (Phan \& Locke, 2015; Poulou, 2007). Although there have been studies on SE, there have been very few on the sources, the antecedents, of SE in the Japanese context. This study aims to investigate Japanese students' sources of SE experiences for EFL speaking and whether any other issues may be contributing towards students' SE.

\section{Methodology}

Data was collected through qualitative semi-structured interviews with 15 students selected from an intact group of second year university students $(N=232)$ majoring in economics at a small, civic university (population 1,400) in Western Japan. The questionnaire was administered in Japanese and is included along with the English version in Appendix A and Appendix B.

There were $129(55.6 \%)$ female and $103(44.4 \%)$ male students. The students were between 18 and 22 yrs. old $(M=19.41, S D=.697)$. Their English level ranged from A1 to
$\mathrm{B} 1(\mathrm{~A} 1=9.9 \%, \mathrm{~A} 2=87.1 \%, \mathrm{~B} 1=3 \%)$. The students first filled in a selection questionnaire comprised of demographic and SE level questions. These were adapted from validated EFL SE scales: 2 items from Piniel and Csizér, (2013), 6 items from Yough, (2011), and 10 items from Wang et al, (2014).

Sixty-one students indicated that they were willing to be interviewed. However, due to students' busy schedules, only 15 students out of the original 61 students responded to requests for interview (4 male and 11 female).

\section{Semistructured Interviews}

An interview protocol was drawn up based on the four sources of SE and general questions to prompt rich student responses (Merriam \& Tisdell, 2016). The interviews lasted between 40 to 90 minutes. Participants were sent participant information sheets one week before the interview and were able to ask any questions before they provided informed consent. Ethical approval was granted from the research site university and aliases were used throughout the study. The interviews were conducted in Japanese and were digitally recorded. They were later transcribed and translated by the author. Translations were checked by two bilingual experts according to the American Translation Association (ATA) translation certification rubric and were found to be strong.

\section{Analysis}

The transcripts were analysed with hybrid, thematic analysis (Swain, 2018). This is a process that draws out the theoretical tenets with a priori (pre-existing) codes whilst also identifying data-driven themes with inductive coding (Fereday \& Muir-Cochrane, 2006). The data were first coded with the four a priori codes from sources of SE: mastery, social modelling, social persuasion and physiological states. Then the data were coded inductively as outlined by Braun and Clarke (2006), to identify any additional themes. Nowell et al.'s, (2017) principles for reliability and validity of thematic analysis were followed. These are credibility, transferability, confirmability, and audit trails. The credibility of the data was checked through assessment of the transcripts against the final coding map. Two Japanese-English bilingual university professors reviewed the themes to evaluate transferability and confirmability. Finally, a complete record of transcriptions, analyses, and researcher field notes were collated to create an audit trail. 


\section{JALT2020}

COMMUNITIES OF

Kobayashi: Sources of Speaking EFL Self-Efficacy of Japanese University Students

\section{Findings}

The background information of the 15 interview participants is shown in Table 1. The participants' English and SE levels were compared with the whole sample $(N=232)$. The interview participants' English levels show 12 out of 15 students had A2 level (80\%) similar to the whole sample (87.1\%). The SE level of the whole sample ranged from 1 to $4.5(M=1.92, S D=.616)$; the participants' $S E$ levels ranged from 1 to $3.7(M=2.16, S D=$ .682). Thus, it was considered that the interview participants were representative of the sample.

Table 1

Background of Interview Participants

\begin{tabular}{lcccc}
\hline Alias & Age & Gender & English CEFR level & English SE level (1-5) \\
\hline Hanako & 19 & female & A2 & 2.8 \\
Minami & 19 & female & A2 & 2.4 \\
Tomoki & 19 & male & A2 & 1.4 \\
Ryuichi & 19 & male & B1 & 3.7 \\
Shiori & 19 & female & A2 & 1 \\
Aya & 19 & female & A2 & 2.6 \\
Yumi & 19 & female & B1 & 2.4 \\
Ayaka & 20 & female & A2 & 2.1 \\
Eri & 19 & female & A2 & 2.2 \\
Ichiro & 19 & male & A2 & 2.3 \\
Rika & 19 & female & A2 & 1.9 \\
Tomomi & 19 & female & A2 & 2.1 \\
Aiko & 20 & female & A2 & 1.8 \\
Yuko & 20 & female & A2 & 1.8 \\
Taro & 20 & male & A1 & 2.7 \\
\hline
\end{tabular}

Note 1: English level is CEFR level (A1 = lowest, $\mathrm{C} 2$ = highest).

Note 2: SE level from selection questionnaire ( $1=$ lowest, $5=$ highest $)$.
The hybrid thematic analysis yielded five themes, the four a priori themes and a fifth inductive theme desired skills. The coding map is shown in Figure 1. Each theme is discussed below with extracts from the interviews.

Figure 1

Coding Matrix after Hybrid Thematic Analysis.

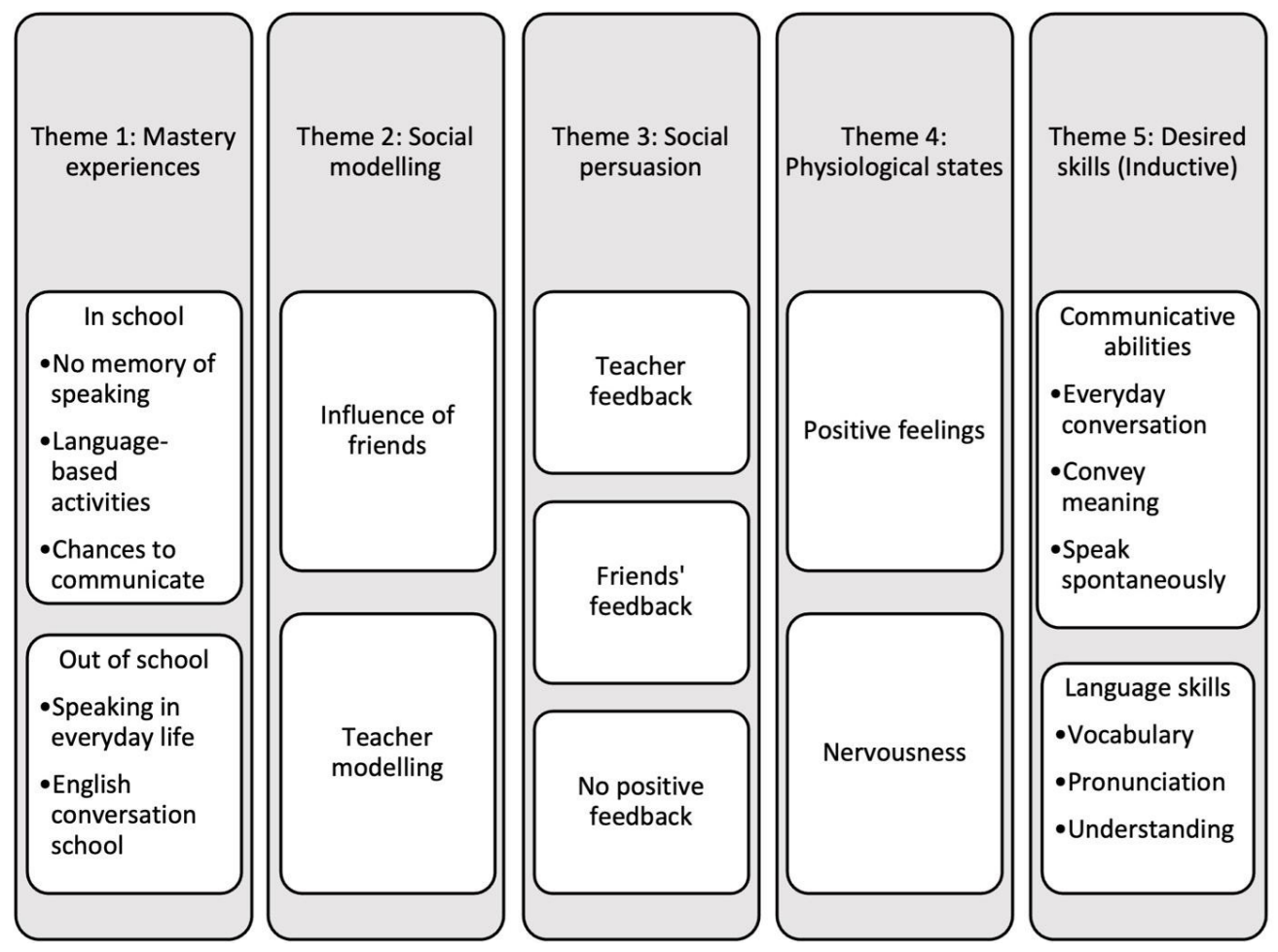

Mastery Experiences

In School

When I asked students about their experiences of speaking English at JSHS, a common response was to say that they could not remember. For example, Hanako commented, "E h... we didn't do much, you know? Not that it wasn't interesting, but I only remember the drama at university. That's how little we did." Similarly, Taro professed, "To be honest, 
I don't remember school. There wasn't really a proper English conversation class." Students recounted mainly passive speaking activities at school. Ichiro described a class activity for practising scripted dialogues with a look of distaste on his face, "Read John's part, read Emily's part, that kind of conversation and we did reading it aloud." Other passive activities were standing in front of the whole class to deliver speeches. Hanako said she remembered, "memorizing the textbook passages because we read out alone, we didn't add gestures or anything, it was just memorizing, it was mainly grammar and writing. We didn't do much speaking."

Yet some students had more communicative opportunities. Minami recounted scripting and performing a roleplay, she spoke with eagerness, “...We were just given that theme and asked what will you do? Um, we thought in each team and then presented." In these activities the students had agency in writing the scripts, but they did not communicate spontaneously. Nevertheless, the interesting topic helped to create a memorable learning experience.

\section{Out of School}

Some of the most engaging experiences students recounted involved unexpected exchanges with foreign people in town. A common feature was students feeling a sense of success from both understanding what the foreign person had said and communicating their thoughts. Eri's comments show how the exchanges, though often challenging, were also seen as rewarding, "But I was really happy to come to understand even a little of those conversations with foreign people."

When communication with foreign visitors was unsuccessful, it proved to be a powerful motivator to improve communicative skills. Minami described giving instructions to a foreign tourist and feeling frustrated about being unable to do so, "At those times, if I don't answer swiftly, they are like 'don't worry'. That's a big shock, so I thought I would study English more."

\section{Social Modelling}

Watching similar others succeed contributes significantly to SE levels. However, students' reflections showed that most did not have enough opportunities to watch others speaking English. Students' main modeller was their teacher, and their experiences were mixed. Some students reported teachers who seldom used English. Shiori talked of the teacher using English, "Just when it was necessary in the lesson", and
Ayaka noted that the lesson was, "Basically in Japanese." However, when teachers used English it had a lasting effect on the students. Tomomi described a teacher who, "Just spoke as usual in the lesson while we were solving the questions, he would ask 'How did you get that answer?' in English, and then we would answer the Japanese teacher like "Well I thought like this." Hanako described the effect of hearing her teacher use English "My motivation went up and it's fun, and I thought I want to hear English more."

Several students said that they had not heard their classmates speak English. Ichiro talked about classmates who consciously decided not to speak English in class, "I listened to those around me, and they were speaking Japanese, so they said like 'Well I can't explain so I'll say it in Japanese', and the worst case was 'Here, read this. "

Students who had friends that spoke English well thought they were amazing. Eri explained the influence of a friend who had been studying English hard, "I felt she was similar to me, but in quite a short time she could speak really well, so I felt that if 1 studied, maybe I could become like that."

\section{Social Persuasion}

Feedback from teachers tended to be constructive criticism designed to help students do better next time and students seemed to appreciate this kind of feedback. Aiko explained that, "When we did the presentation to the teachers, they told us detailed things, so I think that gave us more input." And Aya said, "The teacher pointed out the construction of sentences." Several students remembered teachers giving them negative feedback which focused on students' memorization and pronunciation of the text. Minami said, "It was like whether we had remembered it or not", she also commented that teachers had never told her about her speaking skill. Shiori said that her teacher, "Didn't do much, and that's the point from where I didn't like English."

Comments students received from their friends were also typically about pronunciation. Yuko, who was quite a shy student, sounded delighted when she told me, "I take care when I'm speaking to be easy to understand. I've been told I'm easy to understand." However, classmates' reactions were sometimes unhelpful. Ichiro said that, "There are many people who are stunned, there are not many people who mention advice to me. It finishes with them just being amazed that I speak English." But most students said that they did not receive positive comments from friends. Aiko summed up the students' experiences well, "I only have the chance to speak English in the lesson times, so I didn't get told anything from other people. Amongst my classmates, we didn't say things like that." 
Concerningly, several students had received damaging comments. Tomomi looked uncomfortable while telling me that her Japanese accent was mocked by friends. She confessed that, "I often get told 'you just speak word by word', and I'm told that I speak Japanese English." Similarly, Tomoki told of the teasing that he had received at home. He told me with sadness, "Well my parents don't really, my parents don't really speak English so, sometimes they teased me and said 'Say something in English' and I would halfheartedly say something. l've never been told anything especially advantageous.'

\section{Physiological States}

Students had more negative than positive responses to speaking English. The few cases of feeling positive about speaking were when students had some creative input into deciding what they would say. Ryuichi spoke about a presentation on biomimicry, "It was fun. Being able to use phrases yourself, phrases you've learnt, I experienced that, so first it was enjoyable."

However, most students reported negative reactions to speaking English at school with unpleasant, physical sensations. Shiori's reaction was one of the most vivid, "I was nervous, so I was quite stiff, you know, and I felt the blood drain from my face." Her feelings were mirrored by Minami who talked of "Shaking, I was shaking. I thought I'm embarrassed because I can't speak English. I was embarrassed for everyone to see me speaking."

\section{Desired Skills}

The inductive analysis suggested the final theme of desired skills - the kind of English speaker students wanted to become (Dörnyei, 2009). Desired skills was defined by the communicative abilities they wanted to acquire and the specific language skills they wanted to attain.

Students saw themselves using English to talk about everyday things rather than in their future careers. Taro said, "Well, just using English normally, as much as possible in English, first of all, talk to people, speaking to people." Students also wanted to convey meaning rather than produce grammatically correct phrases. The idea was described by Aya, "When it comes to actual communication, being able to convey meaning is important I think." Many students also expressed a desire to be able to speak spontaneously without first formulating their responses in their head. Tomomi described her frustration with this, "When it came to speaking spontaneously, only the easy English that I learnt at junior high would come out."
The students also talked about the language skills they wanted to have. They wanted to develop their lexical fluency. Ichiro was especially interested in being able to convey the strength of an emotion, "I want to get better at phrases to describe feelings (...) So, I think that I want to be able to express emotional phrases using various vocabulary." Other students wanted to develop core vocabulary. Shiori said that, "I think of what to say in Japanese, don't I? When I think to change it into English, my English vocabulary is often insufficient."

Many students wanted to perfect their English pronunciation. Specifically, they felt that speaking with a Japanese accent was a sign of low aptitude. Tomomi felt that she wanted, "To be able to speak with an understandable pronunciation. I have a strong Japanese intonation, me, I think I want to be able to speak English so that others can understand."

Students also felt that being unable to understand everything that people said to them was the reason that they could not communicate sufficiently. Aiko felt that it was the most important skill, "if I don't know what people are saying, then I can't convey anything, so rather than speaking, I feel I want to get better at listening."

\section{Discussion}

The students' experiences of speaking English at school tended to be giving speeches or reading scripted dialogues aloud. The classroom activities had limited communicative benefit and often did not reflect real world communication. I found this result disheartening because the Ministry of Education, Culture, Sports, Science, and Technology (MEXT, 2012) introduced recommendations that communicative English should be given precedence in order to develop students' international opportunities. It is worrying that in-class learning experiences are inconsistent with student needs because this leads to demotivation (Sakai \& Kikuchi, 2009). The finding is similar to other Japan-based studies, Watanabe, (2013) found that the non-communicative English classes at high school contributed to students' low willingness to communicate. Another study suggests that $66 \%$ of students find experiences of learning speaking EFL at high school unmeaningful (Osterman 2014). Students' active learning experiences were more likely to have occurred out of school talking to foreign people in town. Research suggests that students' experiences of using English in out-of-class activities are a learning strategy that boosts SE (Osboe et al., 2007).

Students' reflections showed that social modelling experiences were also often insufficient. Many students had not been able to hear their classmates speak English, 
but for the few who had, it was an impressive experience. Burrows (2016) found similar results; in his study, students had more meaningful social modelling experiences at university than they did at JSHS. This is important because unlike Western cultures where individuals depend on their own experiences of success, East Asian cultures respond best to group focused instruction (Earley, 1994). Therefore, not observing similar others speaking English meant students lacked valuable SE formation experiences.

The study's findings also suggest that the students had not received enough positive feedback from significant others. Feedback was generally related to students' delivery of speeches and textbook dialogues not communicative ability. Education in Japan draws on the concept of ganbaru (try hard) (Cowie, 2006), where effort rather than self-belief spurs achievement and it seems teacher comments were designed to help students try harder next time. Ruegg (2014) found that constructive feedback from teachers raised Japanese students' SE even when praise was absent. Students reporting that they did not receive any praise could be due to a cultural tendency to avoid embarrassing people, or due to students having few opportunities to converse in lessons. These findings are concerning because not only is SE easier to undermine with negative comments than it is to enhance it with positive ones, but social persuasion may be more influential in East Asian contexts. Therefore, students having little memory of receiving feedback is likely to have significantly diminished their SE to speak EFL.

The students' negative, physiological reactions to speaking English at school were caused by being the focus of everyone's attention. When students are reciting in front of the entire class, they are under everyone's scrutiny, so any mistakes or mispronunciations stand out. However, in conversation, speech is interactional, and a person's focus will be split between what the other person is saying and how they will respond. Research suggests that Japanese students prefer to speak in small groups and that delivering speeches is one of the major sources of student anxiety (Osboe et al., 2007; Williams \& Andrade, 2008). It appears that the prevalence of speaking English in front of the whole class created adverse reactions which diminish SE.

The language abilities and skills that students desired were to quickly convey meaning in everyday conversations, and also to have adequate listening ability, no Japanese accent, and a broad vocabulary. For students, conveying meaning clearly was more important than producing a grammatically correct response. Perhaps this is because speaking activities at school were focused on accuracy at the expense of fluency. There appear to have been insufficient opportunities for students to converse with the need to process information and then formulate a response. The desired skills theme is related to ideal L2 self which is part of the L2 motivational self system proposed by Dörnyei, (2009). Ideal
L2 self refers to the type of $\mathrm{L} 2$ user that students imagine themselves to become. This image stimulates students to try to close the gap between their current perceived L2 self and their future ideal L2 self (Ueki \& Takeuchi, 2013). Although ideal L2 self contains the communicative abilities that students reported in this study, it also includes using the L2 in international work and leisure settings (Dörnyei \& Chan, 2013; Ueki \& Takeuchi, 2012). These kinds of distal goals were not a strong feature in this data set so desired skills is considered as one part of Ideal L2 self.

\section{Conclusion}

The students in this study had a range of sources of SE experiences in learning speaking EFL. It was heartening to hear about students who had dedicated teachers communicate in English enthusiastically, but it was equally discouraging to hear of students who had not had positive learning experiences.

Six key recommendations for teaching can be gleaned from the findings. 1) Speaking practice should be focused on communication by practising non-rehearsed conversations that reflect common interactions in daily and business settings. This kind of practice will help students have positive mastery experiences of speaking EFL through conveying meaning and formulating answers on the fly. 2) Students should have more chances to watch teachers and students use English in the classroom. To this end, English should be used in the classroom as much as possible, not just when necessary. By so doing, its use becomes normalised and speaking in English will not make students stand out. 3) More positive verbal support needs to be given to students. There is some evidence that constructive criticism is as effective as praise in East Asian settings but too many students reported receiving either negative or no feedback. 4) Speaking in front of the whole class causes anxiety and its use should be restricted to when necessary. It should be replaced with speaking in pairs or in small groups whenever possible. 5) Assessment of speaking skills should be based on communicative competence to avoid students fixating on pronunciation and grammatical correctness. 6) Students should be encouraged to form a realistic image of the $\mathrm{L} 2$ speaker they want to become. An image that is not just composed of the skills and abilities they desire but also of using English to communicate in various situations.

Although measures were taken to make this study as reliable and ethically valid as possible, several limitations need to be stated. The lack of responses to requests for interview participation created a self-selection bias in that only students who were willing to be interviewed participated and the experiences reported may not be 
reflective of the student group. Secondly, the self-selection created a gender bias of more than double the number of female participants than male. This means that the male perspective is underrepresented. Finally, the data collected is from one university and may not be transferrable to other contexts. Nevertheless, the study's findings should stimulate more research into speaking EFL SE in the Japanese context.

\section{Bio Data}

Dawn Kobayashi is a teacher researcher based at Onomichi City University in Hiroshima. She is interested in educational psychology and performance in education. (dawnkobayashi@gmail.com)

\section{References}

Baker, W. (2016). English as an academic lingua franca and intercultural awareness: Student mobility in the transcultural university. Language and Intercultural Communication, 16(3), 437-451. https://doi.org/10.1080/14708477.2016.1168053

Bandura, A. (1994). Self-efficacy. In V. S. Ramachaaudran (Ed.), Encyclopedia of human behavior (Vol. 4, pp. 71-81). Retrieved from https://www.uky.edu/ eushe2/Bandura/BanEncy.html

Bandura, A. (2006). Guide for constructing self-efficacy scales. In F. Pajares \& T. Urdan (Eds.), Selfefficacy beliefs in adolescents (pp. 307-337). https://doi.org/10.1017/CBO9781107415324.004

Bandura, A. (2012). On the functional properties of perceived self-efficacy revisited. Journal of Management, 38(1), 9-44. https://doi.org/10.1177/0149206311410606

Braun, V., \& Clarke, V. (2006). Using thematic analysis in psychology. Qualitative Research in Psychology, 3(2), 77-101. https://doi.org/10.1191/1478088706qp063oa

Breaden, J. (2014). Global attributes or local literacy? International students in Japan's graduate employment system. Japan Forum, 26(4), 417-440. https://doi.org/10.1080/09555803.2013.865661

Burrows, L. P. (2016). Retrospective and current levels of self-efficacy in Japanese learners. Indonesian Journal of Applied Linguistics, 6(1), 30-41. https://doi.org/10.17509/ijal.v6i1.2659

Busse, V., \& Walter, C. (2013). Foreign language learning motivation in higher education: A longitudinal study of motivational changes and their causes. Modern Language Journal, 97(2), 435-456. https://doi.org/10.1111/j.1540-4781.2013.12004.x

Cowie, N. (2006). Gambaru: Japanese students' learning persistence. In M. S. \& K. B. Watts (Ed.), Community, identity, motivation:Proceedings of the JALT 2006 international conference on language teaching and learning. Retrieved from https://jalt-publications.org/articles/25720-accessjalt2006-proceedings-articles-here
Dörnyei, Z. (1998). Motivation in second and foreign language learning. Language Teaching, 31(3), 117-135. https://doi.org/10.1017/S026144480001315X

Dörnyei, Z. (2009). The L2 motivational self system [ProQuest Ebook Central version]. In Z. Dörnyei \& E. Ushioda (Eds.), Motivation, language identity and the L2 self. https://doi.org/10.21832/9781847691293

Dörnyei, Z., \& Chan, L. (2013). Motivation and vision: An analysis of future L2 self images, sensory styles, and imagery capacity across two target languages. Language Learning, 63(3), 437-462. https://doi.org/10.1111/lang.12005

Earley, P. C. (1994). Self or group? Cultural effects of training on self-efficacy and performance. Administrative Science Quarterly, 39(1), 89. https://doi.org/10.2307/2393495

Education First. (2019). World ranking of English skills 2019 [Online report]. In EF EPI. Retrieved from https://www.ef.com/assetscdn/WIBlwq6RdJvcD9bc8RMd/legacy/__/ /media/ centralefcom/epi/downloads/full-reports/v10/ef-epi-2020-english.pdf /

Fereday, J., \& Muir-Cochrane, E. (2006). Demonstrating rigor using thematic analysis: A hybrid approach of inductive and deductive coding and theme development. International Journal of Qualitative Methods, 5(1), 80-92. https://doi.org/10.1177/160940690600500107

Hamada, Y. (2008). Demotivators for Japanese teenagers. Pan-Pacific Association of Applied Linguistics, 12(2), 1-23. Retrieved from http://files.eric.ed.gov/fulltext/EJ921015.pdf

Kikuchi, K. (2009). Listening to our learners' voices: What demotivates Japanese high school students? Language Teaching Research, 13(4), 453-471. https://doi. org/10.1177/1362168809341520

Kormos, J., Kiddle, T., \& Csizér, K. (2011). Systems of goals, attitudes, and self-related belief in second-language-learning motivation. Applied Linguistics, 32(5), 495-516. https://doi. org/10.1093/applin/amr019

Lent, R. W., Lopez, F. G., \& Bieschke, K. J. (1991). Mathematics self-efficacy: Sources and relation to science-based career choice. Journal of Counseling Psychology, 38(4), 424-430. https://doi org/10.1037/0022-0167.38.4.424

Lockley, T. (2013). Exploring self-perceived communication competence in foreign language learning. Studies in Second Language Learning and Teaching, 3(2), 187. https://doi.org/10.14746/ ssllt.2013.3.2.3

Matsuda, S., \& Gobel, P. (2004). Anxiety and predictors of performance in the foreign language classroom. System, 32(1), 21-36. https://doi.org/10.1016/j.system.2003.08.002

Merriam, S. B., \& Tisdell, E. J. (2016). Qualitative research: A guide to design and implementation (4th ed.). San Fancisco, USA: Jossey-Bass. 
Mills, N., Pajares, F., \& Herron, C. (2007). Self-efficacy of college intermediate French students: Relation to achievement and motivation. Language Learning, 57(3), 417-442. https://doi. org/10.1111/j.1467-9922.2007.00421.x

Ministry of Education Culture Sports Science and Technology-Japan (MEXT). (2012). Improvemen of Academic Abilities Courses of Study [webpage of policy report]. Retrieved from http://www.mext. go.jp/component/english/__icsFiles/afieldfile/2011/03/17/1303755_013.pdf

Munezane, Y. (2015). Enhancing willingness to communicate: Relative effects of visualization and goal setting. The Modern Language Journal, 99(1), 175-191. https://doi.org/10.1111/modl.12193

Murakami, C., Valvona, C., \& Broudy, D. (2012). Turning apathy into activeness in oral communication classes: Regular self- and peer-assessment in a TBLT programme. System, 40(3), 407-420. https://doi.org/10.1016/j.system.2012.07.003

Nowell, L. S., Norris, J. M., White, D. E., \& Moules, N. J. (2017). Thematic analysis: striving to meet the trustworthiness criteria. International Journal of Qualitative Methods, 16(1), 1-13. https://doi. org/10.1177/1609406917733847

Oettingen, G. (1995). Cross-cultural perspectives on self-efficacy. In Albert Bandura (Ed.), Selfefficacy in changing societies (pp. 149-176). https://doi.org/10.1017/CBO9780511527692.007

Osboe, S., Fujimura, T., \& Hirschel, R. (2007). Student confidence and anxiety in L2 speaking activities. Proceedings of the Independent Learning Association 2007 Japan Conference: Exploring Theory, Enhancing Practice: Autonomy across the Disciplines., 1-11. Retrieved from https://pdfs. semanticscholar.org/e3d5/1187bd4b90a3fa570e25baf33a4cf71a5e57.pdf

Osterman, G. L. (2014). Experiences of Japanese University students' willingness to speak English in class: A multiple case study. SAGE Open, July-Septe(3), 1-13. https://doi. org/10.1177/2158244014543779

Phan, N. T., \& Locke, T. (2015). Sources of self-efficacy of Vietnamese EFL teachers: A qualitative study. Teaching and Teacher Education, 52, 73-82. https://doi.org/10.1016/j.tate.2015.09.006

Piniel, K., \& Csizér, K. (2013). L2 motivation, anxiety and self-efficacy: The interrelationship of individual variables in the secondary school context. Studies in Second Language Learning and Teaching, 3(4), 523-550. https://doi.org/http://dx.doi.org/10.14746/ssllt.2013.3.4.5

Poulou, M. (2007). Personal teaching efficacy and its sources: Student teachers'perceptions. Educational Psychology, 27(2), 191-218. https://doi.org/10.1080/01443410601066693

Rogers, A. (2007). Teaching the speaking skill to Japanese students part 1: Construct and practice. The Journal of Kanda University of International Studies, 20, 1-26. Retrieved from https:// kuis.repo.nii.ac.jp/?action=pages_view_main\&active_action=repository_view_main_item_ detail\&item_id=1270\&item_no=1\&page_id=13\&block_id=17

Ruegg, R. (2014). The effect of peer and teacher feedback on changes in EFL students' writing selfefficacy. The Language Learning Journal, O(0), 1-18. https://doi.org/10.1080/09571736.2014.958 190
Sakai, H., \& Kikuchi, K. (2009). An analysis of demotivators in the EFL classroom. System, 37(1), 57-69. https://doi.org/10.1016/j.system.2008.09.005

Schunk, D. H. (1995). Self-efficacy, motivation, and performance. Journal of Applied Sport Psychology, 7(2), 112-137. https://doi.org/10.1080/10413209508406961

Swain, J. (2018). A hybrid approach to thematic analysis in qualitative research: Using a practical example. In SAGE Research Methods Cases. https://www.doi.org/10.4135/9781526435477

Templin, S. A., Guile, T. C., \& Okuma, T. (2001). Creating a reliable and valid self-efficacy questionnaire and English test to raise learners'L2 achievement via raising their self-efficacy. Presentation at JALT2001. Retrieved from http://www.eric.ed.gov/ERICWebPortal/ contentdelivery/servlet/ERICServlet?accno=ED466625

Todaka, Y. (2017). Self-efficacy of English listening skills in Japanese college EFL learners. European Journal of English Language Teaching, 2(1), 93-120. https://doi.org/doi: 10.5281/zenodo.321540

Toyama, M. (2015). Japanese EFL learners'beliefs about pronunciation learning and their pronunciation skills. Bunkyo University Journal of Language and Culture, May, 92-114. Retrieved from https://bunkyo.repo.nii.ac.jp/?action=pages_view_main\&active_action=repository_view_ main_item_detail\&item_id=3030\&item_no=1\&page_id=29\&block_id=40

Tsuruta, Y. (2013). The knowledge society and the internationalization of Japanese higher education. Asia Pacific Journal of Education, 33(2), 140-155. https://doi.org/10.1080/02188791.2 013.780674

Ueki, M., \& Takeuchi, O. (2012). Validating the L2 motivational self system in a Japanese EFL context: The interplay of L2 motivation, L2 anxiety, self-efficacy, and the perceived amount of information. Language Education \& Technology, 1(22), 1-22. https://doi.org/10.24539/let.49.0_1

Ueki, M., \& Takeuchi, O. (2013). Forming a clearer image of the ideal L2 self: the L2 motivational self system and learner autonomy in a Japanese EFL context. Innovation in Language Learning and Teaching, 7(3), 238-252. https://doi.org/10.1080/17501229.2013.836205

Usher, E. L., \& Pajares, F. (2008). Sources of self-efficacy in school: Critical review of the literature and future directions. Review of Educational Research, 78(4), 751-796. https://doi. org $/ 10.3102 / 0034654308321456$

Usher, E. L., \& Pajares, F. (2009). Sources of self-efficacy in mathematics: A validation study. Contemporary Educational Psychology, 34(1), 89-101. https://doi.org/10.1016/j. cedpsych.2008.09.002

Wang, C., Kim, D.-H., Bai, R., \& Hu, J. (2014). Psychometric properties of a self-efficacy scale for English language learners in China. System, 44, 24-33. https://doi.org/10.1016/j. system.2014.01.015 


\section{JALT2020}

COMMUNITIES OF
TEACHERS \& IEARNERS
Watanabe, M. (2013). Willingness to communicate and Japanese high school English learners. JALT Journal, 35(2), 153-172. Retrieved from http://search.proquest.com/docview/1567036298?accou ntid=14548\%5Cnhttp://metadata.lib.hku.hk/hku?url_ver=Z39.88-2004\&rft_val_fmt=info:ofi/fm $\mathrm{t}:$ kev:mtx:journal\&genre=article\&sid=ProQ:ProQ:llba\&atitle=Willingness+to+Communicate + an $\mathrm{d}+$ Japanese+High+School+English

Williams, K. E., \& Andrade, M. R. (2008). Foreign language learning anxiety in Japanese EFL university classes: Causes, coping, and locus of control. Electronic Journal of Foreign Language Teaching, 5(2), 181-191. Retrieved from http://e-flt.nus.edu.sg/v5n22008/williams.pdf Yough, M. S. (2011). Self-efficacy and the language learner. Ohio State University. Zimmerman, B. J. (1995). Self-efficacy and educational development. In A. Bandura (Ed.), Selfefficacy in changing societies (pp. 202-231). https://doi.org/10.1017/CBO9780511527692

\section{Appendix A}

Japanese Version of Selection Questionnaire

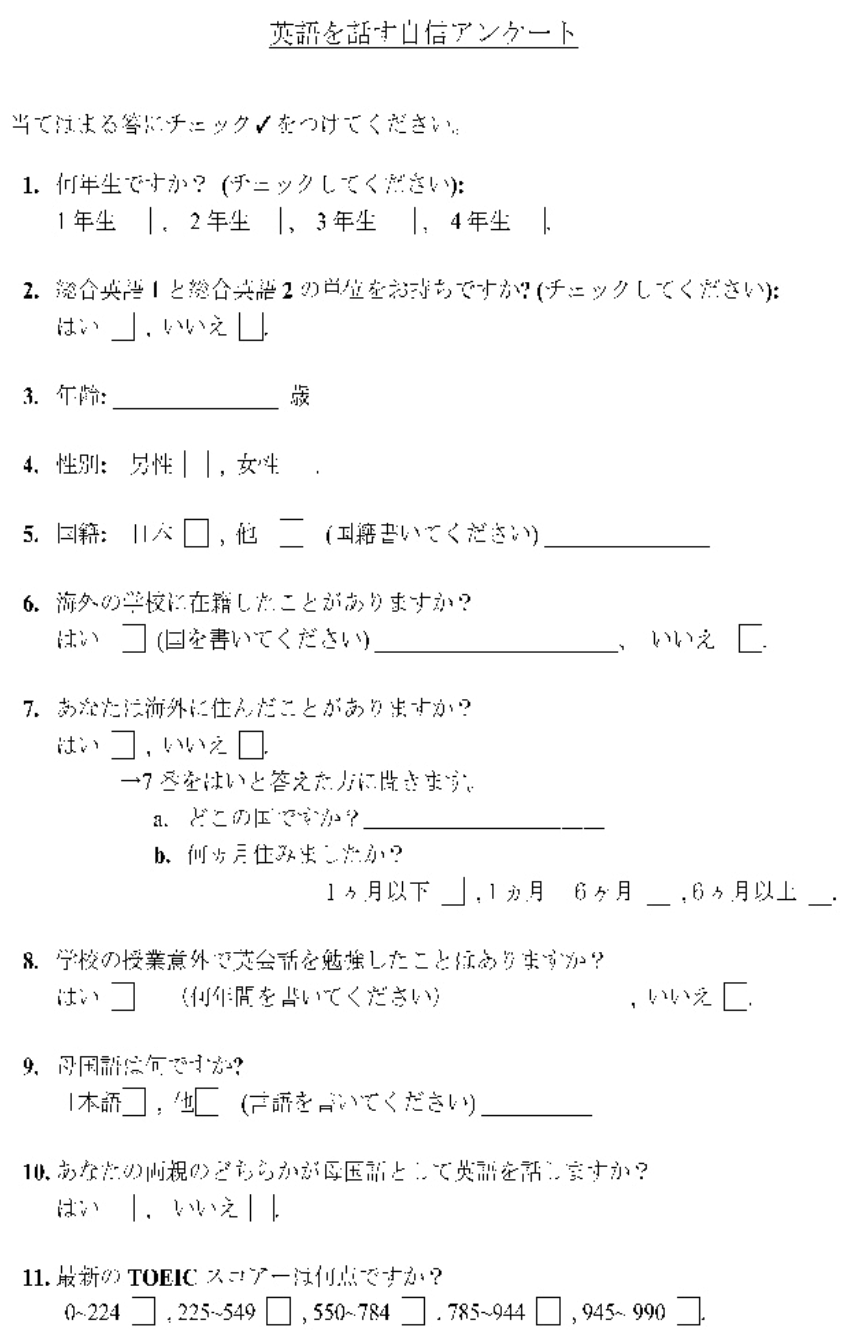

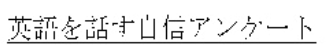

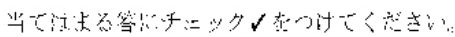

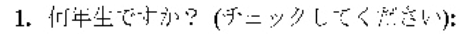

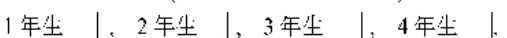

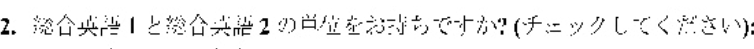

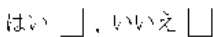

3. 个跡: 歳

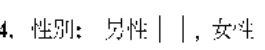

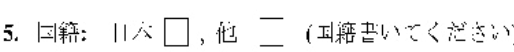

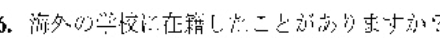

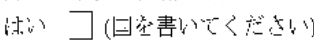
い: $匚$.

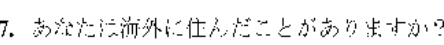

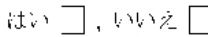

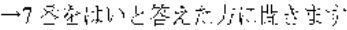

a.

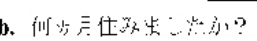

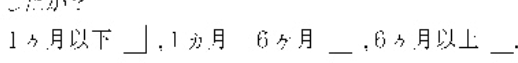

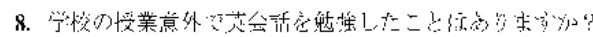

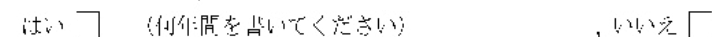

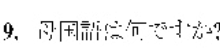

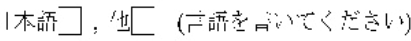

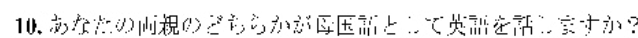

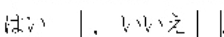

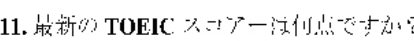
(2. 224$] .225 \sim 549 \square, 550-784] .785 \sim 944 \square, 945 \sim 990]$. 


\section{JALT2020}

TEACHERS \& LEARNERS

\section{英睡老話す自信について}

Directions: 以下のスケールを使って質問に答えてください。あなたの英語を話す自 信についてあてはる番号に○をつけてください。

まったく自信加ない

\begin{tabular}{|c|c|c|c|c|c|}
\hline 1 & 同級生の前で英語を話す & 1 & 2 & 3 & \\
\hline 2 & ネーティブの方と同じ速さで英会話する。 & 1 & 2 & 3 & \\
\hline 3 & 日常的な話題について話している時、自分の意見を伝える。 & 1 & 2 & 3 & 4 \\
\hline 4 & よく分からない話題について 30 分のスピーチをする。 & 1 & 2 & 3 & 4 \\
\hline 5 & よく知っている人と日常会話で英語を使う。 & 1 & 2 & 3 & \\
\hline 6 & 授業時間外に英会話を練習する機会をつくる。 & 1 & 2 & 3 & \\
\hline 7 & 大学の英語授業で行ならスピーキングタスクをする。 & 1 & 2 & 3 & \\
\hline 8 & 大学の英語授業で先生の質問に英語で答える。 & 1 & 2 & 3 & \\
\hline 9 & 他の人に自分の大学について英語で説明する。 & 1 & 2 & 3 & \\
\hline 10 & 自分の住んでいる家から大学までの行き方を英語で説明する。 & 1 & 2 & 3 & \\
\hline 11 & 英語で物語を伝える。 & 1 & 2 & 3 & \\
\hline 12 & 先生に英語で質問をする。 & 1 & 2 & 3 & \\
\hline 13 & 熟語のある英語の文を話す。 & 1 & 2 & 3 & \\
\hline 14 & 自分の先生を、他の人に英語で紹介する。 & 1 & 2 & 3 & \\
\hline 15 & 同級生と一般的な興味を持つ話題について英語で話し合いする & 1 & 2 & 3 & \\
\hline 16 & 字幕なしで英語の映画を理解する。 & 1 & 2 & 3 & \\
\hline 17 & 先生の質問を英語で答える。 & 1 & 2 & 3 & \\
\hline 18 & 自己紹介を英語で言う。 & 1 & 2 & 3 & \\
\hline
\end{tabular}

\section{Appendix B}

English Version of Selection Questionnaire

Student number

\section{Background and EFL Speaking Self-Efficacy Questionnaire}

Background Question

1. Year of study (please check): $\quad 1^{\text {st }} \sqcup, \quad 2^{\text {nd }} \sqcup, \quad 3^{\text {rd }}-, \quad 4^{\text {th }} \sqcup$

2. Have you passed General English 1 and 2? (please check): Yes _ , No $\sqcup$

3. Age yrs. old

4. Gender: Male - Female - Other $\square$

5. Nationality: Japanese $\square$, Other - (please write)

6. In which country did you complete your junior high and high school education?

$$
\text { Japan } \square \text {, Other } \square \text { (please write) }
$$

7. Have you ever lived abroad for a long time (6 months or more)?
Yes $\square$, (where)
(how long?) No -

8. Have you studied English conversation outside of school?

Yes $\square$ How many years? No

9. What is your first language? Japanese $\square$, Other $\square$ (please write)

10. Do either of your parents speak English as a first language? Yes - No

11. What was your latest TOEIC score?

$$
0 \sim 224 \bigsqcup, 225 \sim 549 \_, 550 \sim 784 \ldots, 785 \sim 944\llcorner, 945 \sim 990 \sqcup
$$


JALT2020

COMMUNITIES OF
TEACHERS \& LEARNERS

EFL Speaking Self-Effic acy Questions

Directions: Please use the scale the following scale to answer the questions bel ow. Please circle

the number that best describes how confident you feel to perform the following tasks.
No chance
34
5
Very Confident

\begin{tabular}{|c|c|c|c|c|c|c|}
\hline 1 & Speak the English in front of your classmates & 12 & 2 & 3 & 4 & 5 \\
\hline 2 & $\begin{array}{l}\text { Participate in a conversation at the same speed as a native speaker of } \\
\text { English }\end{array}$ & 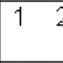 & 2 & 32 & 4 & 5 \\
\hline 3 & Express your opinions in English when speaking about general topics & 12 & 2 & 32 & 4 & 5 \\
\hline 4 & Give a half hour speech on a topic you do not know well in English & 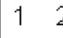 & 2 & 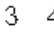 & 4 & 5 \\
\hline 5 & Use English in a casual conversation with people you know & 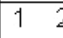 & 2 & 32 & 4 & 5 \\
\hline 6 & $\begin{array}{l}\text { Find or create situations outside of class time to practice conversations } \\
\text { in English }\end{array}$ & 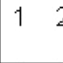 & 2 & 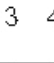 & 4 & 5 \\
\hline 7 & Do the speaking tasks in the university English classes. & 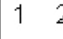 & 2 & 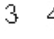 & 4 & 5 \\
\hline 8 & $\begin{array}{l}\text { Answer the teacher's questions in English in the university English } \\
\text { classes. }\end{array}$ & 12 & 2 & 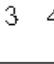 & 4 & 5 \\
\hline 9 & Describe your university to other people in English? & 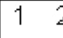 & 2 & 32 & 4 & 5 \\
\hline 10 & $\begin{array}{l}\text { Describe the way to the university from the place where you live in } \\
\text { English? }\end{array}$ & & & 3 & 4 & 5 \\
\hline 11 & Tell a story in English? & 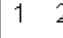 & 2 & 3 & & 5 \\
\hline 12 & Ask your teacher questions in English? & 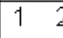 & 2 & 3 & 4 & 5 \\
\hline 13 & Say English sentences with idiomatic phrases? & 12 & 2 & 3 & 4 & 5 \\
\hline 14 & Introduce your teacher to someone else in English? & 12 & 2 & 3 & 4 & 5 \\
\hline 15 & Discuss subjects of general interest with your fellow students in English? & 12 & 2 & 3 & 4 & 5 \\
\hline 16 & Understand English films without subtitles? & 12 & 2 & 3 & 4 & 5 \\
\hline 17 & Answer your teacher's questions in English? & 12 & 2 & 3 & 4 & 5 \\
\hline 18 & Introduce yourself in English? & 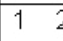 & 2 & 3 & 4 & 5 \\
\hline
\end{tabular}

Thank you for filing in this Questionnaire! 